\title{
COVID-19-Related Studies of Nonprofit Management: A Critical Review and Research Agenda
}

\author{
Márcia R. C. Santos ${ }^{1,2}$ ([) Raul M. S. Laureano ${ }^{2,3}$ (])
}

Accepted: 31 October 2021/Published online: 29 November 2021

(c) International Society for Third-Sector Research 2021

\begin{abstract}
During crises such as the present coronavirus disease-19 (COVID-19) pandemic, nonprofits play a key role in ensuring support to improve the most vulnerable individuals' health, social, and economic conditions. One year into the COVID-19 pandemic, an extensive automated literature analysis was conducted of 154 academic articles on nonprofit management during the pandemic - all of which were published in 2020 . This study sought to identify and systematize academics' contributions to knowledge about the crisis's impact on the nonprofit sector and to ascertain the most urgent directions for future research. The results provide policymakers, nonprofit practitioners, and scholars an overview of the themes addressed and highlight the important assistance academic researchers provide to nonprofits dealing with the COVID-19 pandemic.
\end{abstract}

Keywords COVID-19 - Nonprofit · Management · Crisis · Literature analysis $\cdot$ Critical review

Márcia R. C. Santos

marcia.cadete.santos@gmail.com;

https://ciencia.iscte-iul.pt/mrcss/en

Raul M. S. Laureano

raul.laureano@iscte-iul.pt;

http://ciencia.iscte-iul.pt/rml/en

1 ESCE, Instituto Politécnico de Setúbal, Setúbal, Portugal

2 Information Sciences and Technologies and Architecture Research Center (ISTAR-IUL), Instituto Universitário de Lisboa (ISCTE-IUL), Lisboa, Portugal

3 Business Research Unit (BRU-IUL), Instituto Universitário de Lisboa (ISCTE-IUL), Lisboa, Portugal

\section{Introduction}

The nonprofit sector comprises a multitude of organizations that pursue objectives related to solidarity and community development. During crises, these entities play a key role in ensuring support reaches the most vulnerable individuals in terms of health, social, and economic conditions (Simo \& Bies, 2007). During the coronavirus disease-19 (COVID-19) pandemic, government stay-at-home orders, lay-offs, and school closures contributed to an economic downturn that resulted in thousands of unemployed people and decreased incomes. Due to the lockdown policy, many nonprofits had to deal with an increased demand for food aid, shelter, and other basic necessities.

Even as these organizations came under pressure to supply more support, they lost a significant part of their workforce due to health-related conditions or volunteers' fear of catching the virus. This lack of personnel made the COVID-19 pandemic crisis different from the 2008 financial crisis, when the number of volunteers reached record levels (Tzifakis et al., 2017) and helped the nonprofit sector recover. The reduced workforce during the pandemic presented a massive challenge because volunteers are much more critical in this sector than in the corporate or public sector, given nonprofits' extensive reliance on unpaid helpers (Salamon et al., 2011). Given their absent workforce, many organizations were unable to run programs, raise funds, or serve beneficiaries and/or clients. In addition, nonprofits often have small businesses (e.g., charity shops) that finance other activities, which may have seen revenues drastically decline due to the economic downturn reflected in the European Union's (EU) lower gross domestic product (Eurostat, 2021).

In this unprecedented scenario, the nonprofit sector urgently needs researchers' help to determine how the 
crisis is affecting these organizations' capacity to keep running activities. Nonprofit managers also require a clearer understanding of which strategies to implement in response to emerging challenges, public policies' impacts on their organizations' capabilities, or populations' increased demands for emergency aid. Thus, one year after the COVID-19 pandemic began, one of the most important research problems faced by those who seek to help nonprofit practitioners and promote related scholarship is to identify and systematize academics' contributions to knowledge about the pandemic's impact on the nonprofit sector. Researchers also need information indicating the best directions for future studies on this topic.

The present study thus sought to contribute to efforts to achieve these goals by answering two research questions:

(1) What thematic clusters appeared in the research on nonprofit management during the pandemic's first year?

(2) What future avenues of research still need to be explored regarding nonprofit management during this and future crises?

To address these questions, an extensive automated analysis was conducted of 154 academic articles' abstracts that focus on nonprofit management during the COVID-19 pandemic and that were published in 2020. The bibliometric data were analyzed using descriptive statistics and VOSviewer software to cluster the terms used in the articles' abstracts and create a word co-occurrence map-a popular text mining technique previously applied in similar analyses (Yu et al., 2020; L. Zhang et al., 2020).

The current automated analysis was complemented by an in-depth examination of the articles containing the most significant terms in each cluster. The results provide nonprofit practitioners and scholars with a critical review of the literature on nonprofit management during the first year of the pandemic and with suggested future lines of research on topics that still need to be addressed. Using these results, grounded in theories relevant to nonprofits' challenges - such as the contingency theory of organizations and the unified theory of acceptance and use of technology_-scholars will be able to expand more systematically the existing knowledge about the pandemic's impacts on the nonprofit sector and help policymakers create an agenda for public COVID-19 research funding for this sector.

\section{Methodology}

This study sought to provide a useful, representative assessment of the available bibliometric data on nonprofit management during the COVID-19 pandemic. Both quantitative and qualitative analyses were carried out to classify and systematize the data collected. The quantitative analysis assessed the number of papers published in journals (Mas-Tur et al., 2019). The qualitative analysis, in turn, focused on, among other features, citations per document, which is a helpful indicator of researchers' productivity and their contributions' influence (Modak et al., 2020).

Over the course of 2020, a large number of articles on the COVID-19 pandemic were peer-reviewed and published. To classify these publications, identify their research themes, and unveil significant patterns manually would take a great deal of time. In addition, errors would almost certainly be made, and subjectivity could become a constant. Automated computer analysis methods have been developed to respond to the challenges academics face when analyzing a large volume of bibliometric material (Modak et al., 2020), allowing researchers to provide a representative, informative perspective on the relevant literature in a much shorter time.

After the bibliometric analysis, the identified clusters of related articles were analyzed in greater depth. This critical review provided significant examples of research on prominent themes and identified short- and long-term future directions for studies on this topic. Figure 1 summarizes the procedures applied.

\section{Data Sources and Search Process}

This study used bibliometric data extracted in January 2021 from the Web of Science and Scopus databases, following many previous researchers' example (van Eck \& Waltman, 2010). These databases comprise indexed high-quality, peer-reviewed journals, including publications focused on the nonprofit sector. Given this study's aims, the academic articles selected concentrated on nonprofit management during the COVID-19 pandemic.

Two queries were coded containing nonprofit-related terms and keywords applied with reference to the pandemic. The first set of terms used the lexicon validated and applied by Santos et al. (2020), which was based on Salamon and Sokolowski (2016) and Smith et al. (2006) research. The COVID-19 pandemic keywords were selected from the most recent studies of this topic (Aristovnik et al., 2020; Verma \& Gustafsson, 2020). The search queries (see Appendix 1 in the supplementary material for further details) focused on finding both nonprofit and COVID-19 pandemic-related terms in the title, abstract, or keyword fields specifically for academic articles.

A total of 278 articles on COVID-19 were retrieved, of which 124 addressed medical topics. The latter articles had already been reviewed by Yu et al. (2020), so these publications were excluded from the present analysis to restrict 
Fig. 1 Research strategy

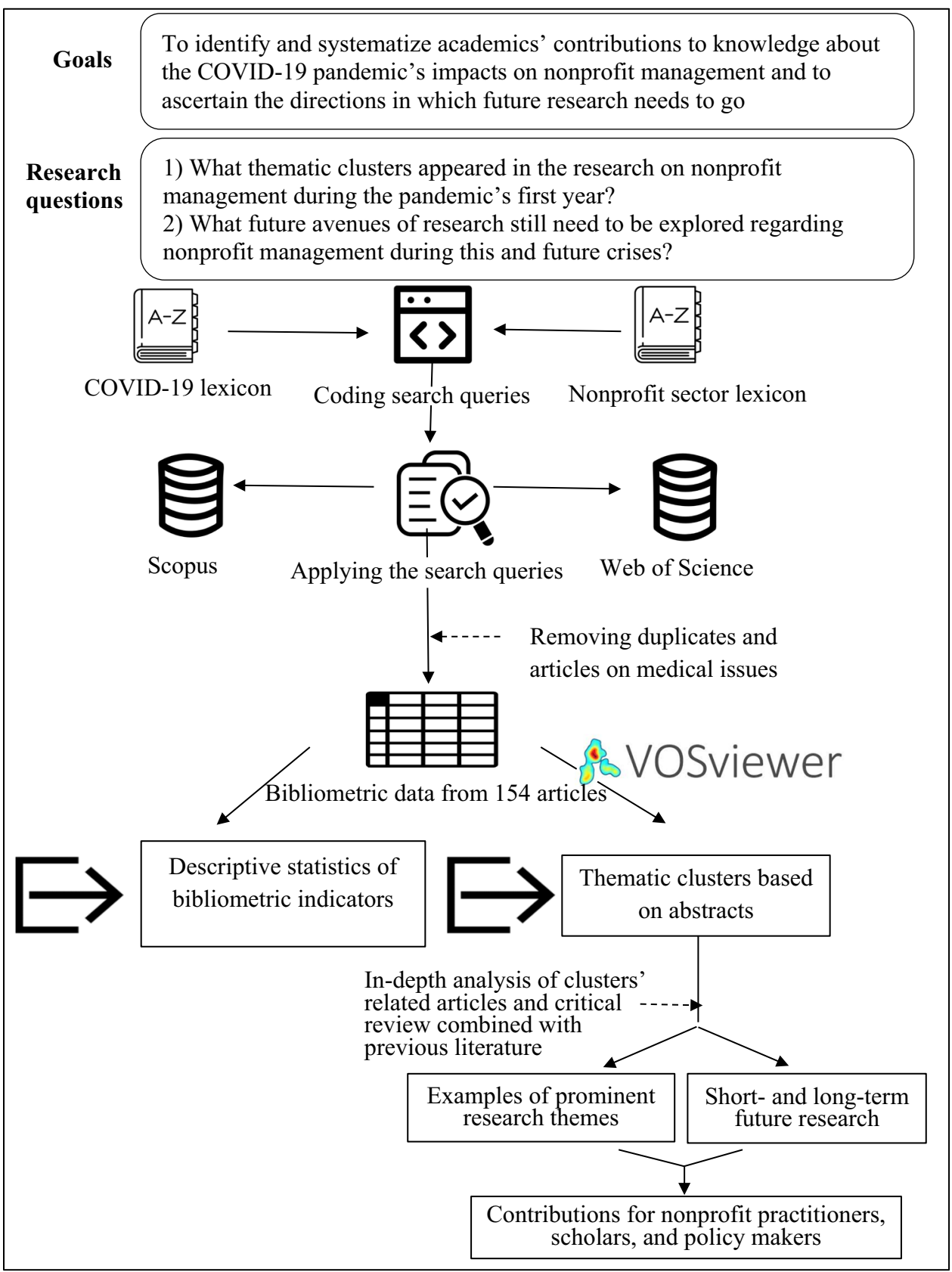

this study to research on nonprofit management issues other than medical treatments and diagnoses. The final sample thus included 154 academic articles published in 2020 in 118 different journals produced by 54 distinct publishers.

\section{Articles' Profile}

The 154 articles on nonprofit management during the COVID-19 pandemic were written by 589 researchers. Of the latter, 37 appear as an author or co-author in two articles, which is the highest number of articles per author. Co-authorship is the most common given that $75 \%$ of the articles have 2 or more authors, although half the articles published $(49 \%)$ were authored by 1 or 2 researchers. This percentage increases to $71 \%$ for articles written by $1-3$ authors.

An analysis of the authors' affiliations revealed that the northern hemisphere contains most of the research centers (see Table 1) as Europe and North America represent 62\% of the researchers. For each study conducted by research teams based in South America, more than four studies were conducted in North America. Research in underdeveloped countries is in the minority. Overall, scholars affiliated with institutions in Europe (59) and North America (55) are the 
Table 1 Article count by continent and regions with which research teams are affiliated in 2020

\begin{tabular}{llll}
\hline Continent/Region & Total & Continent/Region & Total \\
\hline Europe & $\mathbf{5 9}$ & South America & $\mathbf{1 3}$ \\
Northern Europe & 34 & South America & 13 \\
Southern Europe & 13 & Africa & $\mathbf{1 1}$ \\
Western Europe & 8 & Southern Africa & 4 \\
Eastern Europe & 4 & Eastern Africa & 3 \\
North America & $\mathbf{5 5}$ & Western Africa & 2 \\
Northern America & 55 & Middle Africa & 1 \\
Caribbean & 0 & Northern Africa & 1 \\
Central America & 0 & Oceania & $\mathbf{7}$ \\
Asia & $\mathbf{4 0}$ & Australia and New Zealand & 5 \\
Eastern Asia & 15 & Polynesia & 1 \\
Southern Asia & 9 & Melanesia & 1 \\
South-eastern Asia & 9 & Micronesia & 0 \\
Western Asia & 7 & Antarctica & $\mathbf{0}$ \\
Central Asia & 0 & Antarctica & 0 \\
Grand total 185 & & &
\end{tabular}

top contributors, followed by Asia (40), where most studies took place in China (12) as it was the country in which the virus first started spreading. Other research focused on regions of South America (13) and Africa (11), including but not limited to Brazil (3), Colombia (4), Peru (3), and South Africa (4).

The impact and perceived quality of researchers' contributions were measured using the indicator "number of citations," which revealed that less than one-third of the articles (46 articles or 30\%) had already been cited-85\% of which were open access. The articles had been cited 196 times in total, with an average of 4 citations per article cited and an average of 1.56 citations when all the sample's open access articles were included. This key indicator is significantly lower (i.e., 3 citations) per non-open access article cited and an average of 0.62 citations when all the non-open access articles were considered.

The American Review of Public Administration is the journal that published the most articles (7), followed by Nonprofit and Voluntary Sector Quarterly (6) and Public Administration Review (4). The latter journal published the most cited articles (18 citations). The publishers of most of the articles included in the sample are SAGE (31), Springer (13), Emerald (13), Routledge (11), and Elsevier (8). Table 2 summarizes the top-three journals, publishers, and number of citations.

The overwhelming majority are articles written in English (94\%), although some articles are in Hungarian, German, Italian, Portuguese, or Spanish. A significant number of articles (49) disclose receiving financial support to cover research, authorship, and/or publication costs.

\section{Data Analysis}

Text mining techniques can unveil the hidden patterns in texts such as documents, comments, or reviews (Calheiros et al., 2017). With these techniques, researchers can search texts for terms composed of one or more words and uncover patterns based on the frequency with which these terms appear in texts (Santos et al., 2020). To apply text mining to the present sample of abstracts, two procedures were followed to ensure that only meaningful words were included, namely stemming and stop word removal (Guerreiro et al., 2016). Stemming allowed the analysis to consider equivalent words with the same meaning but with, for instance, different prefixes and suffixes. Stop word removal eliminated irrelevant words (e.g., "the," "a," and "or") or the specific words used to select the literature sample (e.g., "COVID-19" or "SarS-Cov-2").

The new dataset created by these procedures, known as the "corpus," was the input for the co-word analysis, which used text mining techniques to identify links between words when they occurred together in the same text (van Eck \& Waltman, 2010). VOSviewer is an open-source software that helps researchers conduct this type of analysis based on word co-occurrence using a natural language processing algorithm provided by the Apache OpenNLP library, a machine learning-based toolkit for clustering (Wang et al., 2021). This software is also well suited for use in data analysis and visualization. The present study followed the lead of the many scholars who have used this software to conduct bibliometric analyses focused on emerging research trends, namely in business and management (Shah et al., 2019; Verma \& Gustafsson, 2020) or on general topics such as the COVID-19 pandemic (Aristovnik et al., 2020; Yu et al., 2020).

VOSviewer has proven to be useful for creating network maps of co-occurrence links between words present in bibliometric data (i.e., title, abstract, and keywords), which highlight clusters in emerging research. Each word belongs to only one cluster, and all the words belonging to a cluster appear in the same color on the VOSviewer map visualizing the network of words. This technique provides more advantages than other clustering techniques (van Eck \& Waltman, 2009).

Using VOSviewer analysis tools, the current study categorized the selected articles' themes with reference to a semantic similarity and association strength matrix based on the co-occurrence of $60 \%$ of the most significant terms, namely those that occurred more than 10 times in the articles' abstracts. The analysis produced five thematic clusters. Finally, a manual in-depth analysis was carried 
Table 2 Summary of top-three journals, publishers, and number of citations in 2020

\begin{tabular}{|c|c|c|}
\hline $\begin{array}{l}\text { Article } \\
\text { Information }\end{array}$ & $\begin{array}{l}\text { Total no. of items in } \\
\text { the sample }\end{array}$ & Top three \\
\hline Journals & 118 & $\begin{array}{l}\text { - American Review of Public Administration } \\
\text { - Nonprofit and Voluntary Sector Quarterly } \\
\text { - Public Administration Review }\end{array}$ \\
\hline Publishers & 54 & $\begin{array}{l}\text { - SAGE } \\
\text { - Springer } \\
\text { - Emerald }\end{array}$ \\
\hline $\begin{array}{l}\text { Article } \\
\text { citations }\end{array}$ & 196 & $\begin{array}{l}\text { - The COVID-19 pandemic, small-scale fisheries and coastal fishing communities (Bennett et al., } \\
\text { 2020) } \\
\text { - Slum health: Arresting COVID-19 and improving well-being in urban informal settlements (Corburn } \\
\text { et al., 2020) } \\
\text { - Toward sustainable learning during school suspension: Socioeconomic, occupational aspirations, and } \\
\text { learning behavior of Vietnamese students during COVID-19 (Tran et al., 2020) }\end{array}$ \\
\hline
\end{tabular}

out of the articles containing the most important terms within each cluster to provide significant examples of research on prominent themes.

Nonprofits' management faced specific challenges arising from the immediate impacts of the COVID-19 pandemic. This study conducted a critical analysis of emerging topics related to the crisis, combining previous literature addressing management theories, perspectives, methods, and tools in order to propose guidelines for future research. The results thus include short- and long-term topics to be addressed by academics.

\section{Results}

As mentioned previously, the clustering procedures were based on the co-occurrence of words, allowing to reveal thematic clusters and future research topics.

\section{Thematic Clusters}

VOSviewer generated the network visualization map shown in Fig. 2. Each color in the map identifies a cluster to which the articles were assigned. The larger the cluster's term and circumference are, the more often the included terms occurred in all the articles, based on full counting statistics.

The five identified thematic clusters within the literature on nonprofit management in the COVID-19 pandemic context were labeled as follows: technology (Cluster 1), citizens (Cluster 2), collaborative models (Cluster 3), healthcare access (Cluster 4), and civil society participation (Cluster 5). Table 3 lists the most frequent terms in each cluster and each term's number of occurrences.

Cluster 1 -shown in red-includes 13 terms that fall within research on technology, in which practice, technology, and university are the most frequent terms. This cluster covers studies investigating personnel's adoption of technologies to steer activities during government-mandated lockdown periods to contain COVID-19's spread. Technology was also used to increase interactions between organizations.

The authors contributing to this cluster provide evidence that technologies offer competitive advantages and, in times when people cannot meet face-to-face, technology is a tool for survival and for enabling social businesses' creation, among other functions (Akpan et al., 2020). Other researchers discuss the growing power of people and organizations that produce new digital technologies, as well as how the COVID-19 pandemic has affected cities' ability to counteract the technology industry's negative effects. Through public-private-nonprofit partnerships, municipalities have continued to create technology jobs without leaving embedded industries and social communities unprotected (Singh et al., 2020).

According to Maserat et al. (2020), Web portals have increased information security, improved the ability to find needed information, and facilitated communication between organizations during the COVID-19 pandemic. These portals thus strengthen the collaboration between health-related non-governmental organizations (NGOs) and universities' medical science departments.

Cluster 2-shown in green-includes 10 terms related to research on citizens, focusing on the negative consequences to children and families of restrictive measures and nonprofits' decreased capacity to provide services. These academic studies contribute to a better understanding of the COVID-19 pandemic and associated responses' impacts on refugees, students, children, and families and offer data-informed recommendations to public and private service providers working with these populations. Nisanci et al. (2020) used their experience working in NGOs in 
Fig. 2 VOSviewer cooccurrence of terms map

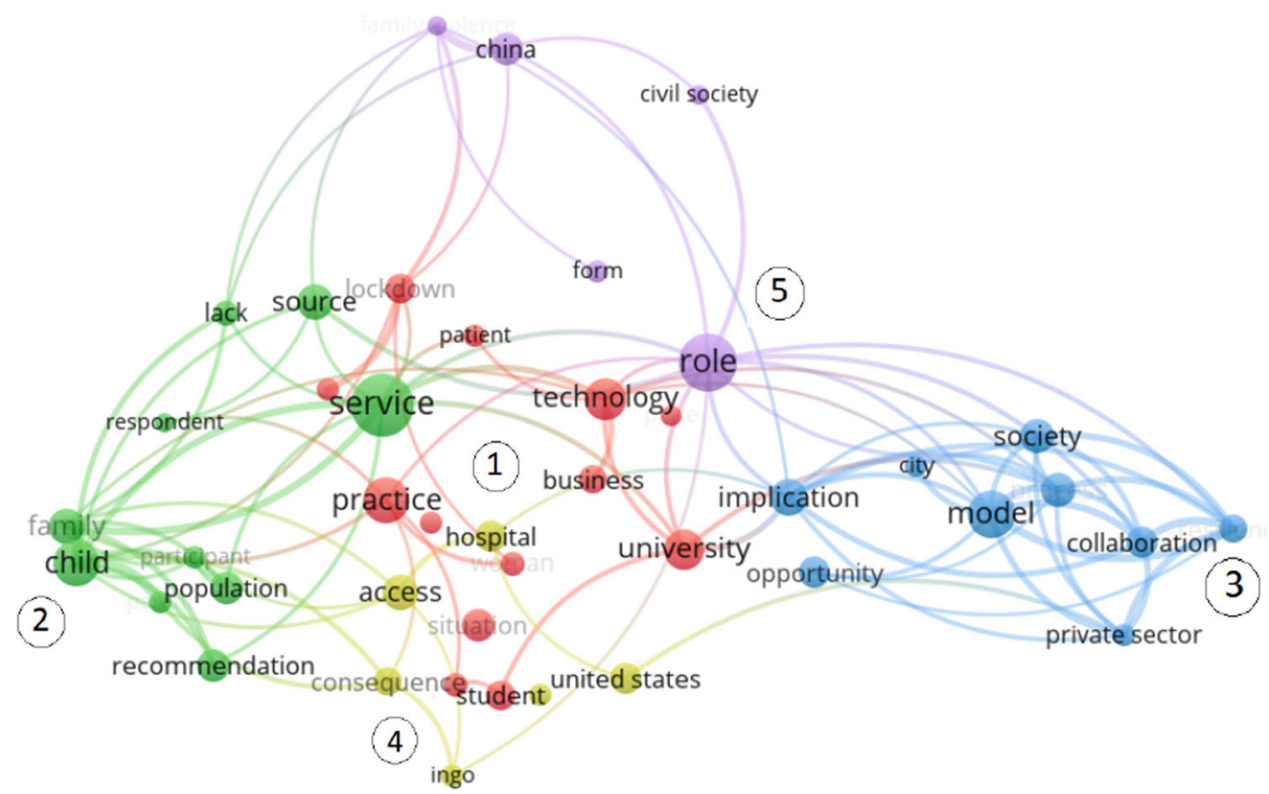

different cities in Turkey to highlight these organizations' vital role in delivering psychosocial support services to refugees, suggesting new measures that can be taken in the near future.

Researchers also sought to unveil the pandemic's devastating effects on students, documenting cross-sector collaboration among schools, universities, nonprofits, and other organizations to leverage resources needed to support teachers and students (Berry, 2020). These efforts included help for parents, especially those with children with developmental challenges, who experienced additional stress from both restrictive measures and distance learning's demands (Lučić et al., 2020). In addition, the most vulnerable children and families were a specific focus. The cited authors report that restrictive measures caused these children and families to see themselves as deprived of access to vital services. These families were also unprepared to deal with cohabitation when residential care providers suddenly returned adolescents, children, and older youths to their family, who were sometimes unable to care for them.

Pitts (2020) also examined the consequences of COVID19 restrictions on illicit drug users and vulnerable children and young people. The cited study highlighted increased violence and likelihood of arrest and the recruitment of young people and children into illicit drug trade as serious concerns. Concurrently, the NGOs supporting all these populations experienced decreased financial support, thereby becoming unable to provide adequate services to the families they normally assist (Rossitto, 2020; Wilke et al., 2020a, b).

Cluster 3-shown in blue-comprises nine terms covering research on the collaborative models applied by different actors and nonprofits, especially those that emerged during the crisis. The main studies addressing this topic focus, more specifically, on government-nonprofit collaborations. Zhao and Wu (2020) show that diverse collaborative channels between citizens and government can generate different results, especially with regard to the government-organized or self-organized NGOs that emerged as informal channels for citizens to fight against COVID-19.

Other scholars analyzed experiences in which government volunteers provided technical assistance to NGOs in order to supplement their expert human resources and enable these organizations to apply for funding (Tierney \& Boodoosingh, 2020). Evidence for this cooperative strategy was found by a nationwide survey of nonprofit foundations. The survey results show that most of these organizations partnered with other nonprofit or public sector organizations (Finchum-Mason et al., 2020).

Cluster 4-shown in yellow-includes six terms from research on healthcare access, particularly studies related to access to these services in the USA. The related research examined the authorities' communication strategies and practices implemented to ensure public health instructions were followed. This cluster's articles further discuss community leaders of religious congregations and faith-based organizations' struggles and successes with establishing relationships with hospitals, as well as efforts led by school leaders, elected officials, and housing association representatives (Galiatsatos et al., 2020).

The relevant studies also analyzed techniques that healthcare centers (e.g., hospitals) applied to deliver services to citizens. For instance, Williams et al. (2020) studied the use of intensive care unit telemedicine (tele- 
Table 3 Clusters' profile

\begin{tabular}{|c|c|c|c|}
\hline Cluster & $\begin{array}{l}\text { Most frequent } \\
\text { terms }\end{array}$ & $\begin{array}{l}\text { Number of terms' } \\
\text { occurrences }\end{array}$ & References \\
\hline \multirow{6}{*}{$\begin{array}{l}\text { Cluster \#1: technology }(\text { red })=13 \\
\text { terms }\end{array}$} & Practice & 34 & \multirow[t]{6}{*}{ Akpan et al. (2020); Maserat et al. (2020); Singh et al. (2020) } \\
\hline & Technology & 29 & \\
\hline & University & 28 & \\
\hline & Situation & 21 & \\
\hline & Student & 19 & \\
\hline & Lockdown & 18 & \\
\hline \multirow{6}{*}{$\begin{array}{l}\text { Cluster \#2: citizens }(\text { green })=10 \\
\text { terms }\end{array}$} & Service & 51 & \multirow{6}{*}{$\begin{array}{l}\text { Berry (2020); Lučić et al. (2020); Nisanci et al. (2020); Pitts } \\
\text { (2020); Rossitto (2020); Wilke et al. (2020a, b) }\end{array}$} \\
\hline & Child & 34 & \\
\hline & Family & 24 & \\
\hline & Source & 23 & \\
\hline & Recommendation & 21 & \\
\hline & Population & 21 & \\
\hline \multirow{6}{*}{$\begin{array}{l}\text { Cluster \#3: collaborative models } \\
\text { (blue) }=9 \text { terms }\end{array}$} & Model & 35 & \multirow{6}{*}{$\begin{array}{l}\text { Finchum-Mason et al. (2020); Tierney and Boodoosingh (2020); } \\
\text { Zhao and Wu (2020) }\end{array}$} \\
\hline & Implication & 25 & \\
\hline & Society & 22 & \\
\hline & Process & 22 & \\
\hline & Collaboration & 20 & \\
\hline & Opportunity & 20 & \\
\hline \multirow{5}{*}{$\begin{array}{l}\text { Cluster \#4: healthcare access } \\
\text { (yellow) }=6 \text { terms }\end{array}$} & Access & 23 & \multirow[t]{5}{*}{ Galiatsatos et al. (2020); Williams et al. (2020) } \\
\hline & US & 20 & \\
\hline & Hospital & 20 & \\
\hline & Consequence & 17 & \\
\hline & Demand & 13 & \\
\hline \multirow{5}{*}{$\begin{array}{l}\text { Cluster \#5: civil society } \\
\text { participation (purple) }=5 \text { terms }\end{array}$} & Role & 45 & \multirow[t]{5}{*}{ Ding and Riccucci (2020); H. Zhang (2020) } \\
\hline & China & 21 & \\
\hline & Form & 12 & \\
\hline & Civil society & 10 & \\
\hline & Family violence & 10 & \\
\hline
\end{tabular}

ICUs) in rural parts of the USA. The findings include that, among other characteristics, nonprofit hospitals' participation in health systems is more likely to involve teleICUs.

Finally, Cluster 5-shown in purple-includes five terms from research on civil society participation, including studies specifically focused on China's realities-the country where the new coronavirus first started spreading. Academics investigated how nonprofit alumni networks can be used to assist shared struggles, in general, and help to solve major public challenges, suggesting future directions for research on these networks' value from a public administration perspective (Ding \& Riccucci, 2020).

Regarding the pandemic's negative impact in terms of increasing family violence, (H. Zhang, 2020) reports alarming statistics on domestic violence due to patriarchal attitudes deeply embedded in Chinese society. The cited author argues that NGOs need to take a more active role on providing appropriate, immediate assistance to abuse victims during the pandemic by updating their information and resources. Locally provided services must include general guidelines for critical emotional support and counselling services, protective services, legal advice, crisis helplines, and emergency shelters. NGOs should also design and publish specific rules regarding domestic violence to help families endure long-term home isolation.

\section{Short- and Long-Term Avenues for Future Research}

The insights provided by clustering highlight scholars' important contributions to supporting nonprofits dealing with this pandemic, but much room is still left to expand the existing knowledge in this area of research. To advance 
academics' efforts further, this subsection outlines an agenda for future studies of nonprofit management, which is divided into short- and long-term topics.

In the near future, governments will actively expand the supply of COVID-19 vaccines to their populations. A window of hope should open in all sectors of activity allowing nonprofits to resume more continuous operations due to the expected reduction of restrictive rules after vaccination. In this evolving context, specific challenges for nonprofits have arisen out of the COVID-19 pandemic's immediate impacts, generating a set of short-term topics that need to be addressed by academics. These topics are summarized in Table 4, which connects the topics to the clusters and also to the nonprofit areas and challenges.

Short-term goals involve restoring or maintaining nonprofit organizations' capacity to provide services through fundraising and attracting and maintaining material and human resources since these organizations are currently struggling financially (Deitrick et al., 2020). Regarding fundraising, federal and national funding campaigns will eventually start, and nonprofits must be prepared to draft well-structured proposals and comply with technical guidelines to gain access to public funds. Thus, nonprofits need to ensure their staff are sufficiently professionally qualified to address proposals' regulatory aspects and quality standards. Researchers can contribute to identifying successful applications' determinant factors during crises. In addition, studies should provide managerial frameworks and highlight best practices for managing relationships between funders and nonprofits, which can become tense due to constraints on specific funding programs and their need to maintain a focus on project outcomes (Shaw \& Allen, 2009).

In terms of attracting resources, fundraising campaigns have never completely stopped, but, in socioeconomic crises, donations necessarily decrease (Brañas-Garza et al., 2020). When working from home is the rule and e-commerce becomes a significant trend, the Internet becomes the main tool for fundraising. Research on social media's impacts is not new in the nonprofit sector. Scholars have already confirmed, for instance, the online organizational content individual stakeholders prefer (Saxton \& Waters, 2014), determinants of online giving (Saxton \& Wang, 2014), and aspects of organizational identity construction using digital platforms (Ruelle \& Peverelli, 2016). Nonprofits' online presence was found to be significantly related to their resources' stability during the 2008 financial crisis (Arik et al., 2016). Scholars can thus help predict donors' attitudes toward contributing online to fundraising campaigns during the COVID-19 pandemic (Bin-Nashwan et al., 2020), but studies on this topic are still rare.

New trends have emerged, namely webpages for writing reviews of and/or providing feedback to organizations
(Park et al., 2020), crowdfunding platforms' role in sharing campaigns (de Broeck, 2018), and the part played by influencers and celebrities' appeals for donations (Tafesse \& Wood, 2021). Researchers need to explore how important donation patterns using these new communication strategies are and how nonprofits can identify the best ways to develop related fundraising campaigns. Investigations focused on this topic should not be limited to proposing theoretical models but instead also conduct case studies to explore successful strategies and innovative managerial tools used to monitor these strategies' effects on performance (e.g., dashboards) (Fernandes et al., 2021).

Regarding attracting human resources, nonprofits currently face both the challenge of reengaging volunteers who interrupted their collaboration and engaging new volunteers despite the ongoing pandemic so that these organizations can provide services. Interruptions have been due to, for instance, volunteers' unwillingness to expose themselves to severe acute respiratory syndrome coronavirus- 2 or their need to dedicate time to their children due to school closures. In addition, extra time had to be invested in adapting to new distance work methods that require workers to dedicate more time to their jobs (Selamet, 2020). These realities have combined with nonprofits' partial or exclusive use of distance service provision (Deitrick et al., 2020) to create more challenges in terms of attracting volunteers.

Given nonprofits' struggle to attract and retain their workforce, scholars could identify the factors influencing volunteers' levels of engagement during the pandemic crisis, as well as proposing innovative conceptual, theoretical, and analytical frameworks. Other relevant topics are assessments of new strategies to help nonprofits identify, recruit, and train volunteers so that these organizations are prepared to serve target populations in both on-site and distance modes. The existing literature on these areas needs to be strengthened (Baxter-Tomkins \& Wallace, 2009). Researchers should further analyze digital volunteer training formats' effectiveness and the adaptations needed to convert on-site work to distance services - a new challenge that emerged with the COVID-19 pandemic. Validations are needed of successful strategies for dealing with this crisis so that nonprofits can decide whether to implement these strategies or maintain others based on their successful implementation in the past (Trautmann et al., 2007).

Communication strategies must be analyzed to help nonprofits assess how social media can be used to attract volunteers, namely examining social media comments, likes, or reviews posted by users. Research can provide highlights through sentiment analysis of the positive or negative feedback generated (Selamet, 2020) by, for example, sharing past volunteering experiences in nonprofit organizations or beneficiaries' online thanks in posts. 
Table 4 Nonprofits' challenges and short-term future research on nonprofit management

\begin{tabular}{|c|c|c|c|c|}
\hline $\begin{array}{l}\text { Related } \\
\text { clusters }\end{array}$ & $\begin{array}{l}\text { Nonprofit } \\
\text { area }\end{array}$ & $\begin{array}{l}\text { Nonprofits' } \\
\text { challenge }\end{array}$ & Future research topic & References \\
\hline $\begin{array}{l}\text { Cluster } 1 \\
\text { technology; } \\
\text { Cluster } 3 \\
\text { collaborative } \\
\text { models; }\end{array}$ & \multirow[t]{2}{*}{ Fundraising } & $\begin{array}{l}\text { Submitting } \\
\text { successful grant } \\
\text { applications }\end{array}$ & $\begin{array}{l}\text { \#1: Identifying factors in applications' } \\
\text { success during crisis } \\
\text { \#2: Designing managerial frameworks and } \\
\text { finding best practices for managing } \\
\text { relationships between funders and } \\
\text { nonprofits }\end{array}$ & \multirow[t]{2}{*}{$\begin{array}{l}\text { Arik et al. (2016); Bin-Nashwan et al. } \\
\text { (2020); de Broeck (2018); Fernandes } \\
\text { et al. (2021); Park et al. (2020); Ruelle } \\
\text { and Peverelli, (2016); Saxton and Wang } \\
\text { (2014); Saxton and Waters (2014); Shaw } \\
\text { and Allen (2009); Tafesse and Wood } \\
\text { (2021) }\end{array}$} \\
\hline $\begin{array}{l}\text { Cluster } 5 \text { civil } \\
\text { society } \\
\text { participation }\end{array}$ & & $\begin{array}{l}\text { Running successful } \\
\text { social media and } \\
\text { crowdfunding } \\
\text { campaigns }\end{array}$ & $\begin{array}{l}\text { \#3: Investigating the role of influencers and } \\
\text { celebrities' appeals for donations, the } \\
\text { impact of reviews of and/or feedback to } \\
\text { nonprofit organizations or use of } \\
\text { crowdfunding platforms in fundraising } \\
\text { campaigns } \\
\text { \#4: Conducting case studies to explore } \\
\text { highly successful strategies and } \\
\text { innovative managerial tools to monitor } \\
\text { fundraising results using different } \\
\text { strategies and/or approaches (e.g., } \\
\text { dashboards) }\end{array}$ & \\
\hline $\begin{array}{l}\text { Cluster } 5- \\
\text { civil society } \\
\text { participation }\end{array}$ & \multirow[t]{3}{*}{$\begin{array}{l}\text { Human } \\
\text { resources }\end{array}$} & \multirow[t]{3}{*}{$\begin{array}{l}\text { Attracting and } \\
\text { engaging } \\
\text { volunteers }\end{array}$} & $\begin{array}{l}\text { \#5: Identifying the factors influencing } \\
\text { volunteers' engagement during pandemic } \\
\text { crises }\end{array}$ & \multirow[t]{3}{*}{$\begin{array}{l}\text { Ortigosa et al. (2014); Selamet (2020); } \\
\text { Trautmann et al. (2007); Baxter-Tomkins } \\
\text { and Wallace (2009) }\end{array}$} \\
\hline $\begin{array}{l}\text { Cluster } 3- \\
\text { collaborative } \\
\text { models }\end{array}$ & & & $\begin{array}{l}\text { \#6: Proposing innovative conceptual, } \\
\text { theoretical, and analytical frameworks } \\
\text { and assessing new strategies to help } \\
\text { nonprofits identify, recruit, and train } \\
\text { volunteers based on online service } \\
\text { provision formats }\end{array}$ & \\
\hline $\begin{array}{l}\text { Cluster 1- } \\
\text { technology }\end{array}$ & & & $\begin{array}{l}\text { \#7: Analyzing the effectiveness of digital } \\
\text { volunteer training formats and distance } \\
\text { service provision's impacts } \\
\text { \#8: Investigating the effects of social media } \\
\text { comments, likes, or reviews of past } \\
\text { volunteering experiences on volunteer } \\
\text { attraction and engagement, using a data- } \\
\text { driven approach }\end{array}$ & \\
\hline $\begin{array}{l}\text { Cluster } 1- \\
\text { technology } \\
\text { Cluster } 3- \\
\text { collaborative } \\
\text { models }\end{array}$ & Technology & $\begin{array}{l}\text { Mitigating } \\
\text { technological } \\
\text { gaps }\end{array}$ & $\begin{array}{l}\text { \#9: Identifying best practices for } \\
\text { establishing partnerships to obtain unused } \\
\text { equipment from companies and the public } \\
\text { sector } \\
\text { \#10: Identifying opportunities and risks } \\
\text { associated with interorganizational } \\
\text { networks in which collaborative strategies } \\
\text { based on technology are explored to } \\
\text { promote nonprofits' resilience } \\
\text { \#11: Validating the theory of acceptance } \\
\text { and use of technology for nonprofits in } \\
\text { crisis contexts }\end{array}$ & $\begin{array}{l}\text { Bell et al. (2015); Chege et al. (2020); } \\
\text { Martínez (2003); (Curtis et al., 2010) }\end{array}$ \\
\hline
\end{tabular}

Automated analyses are needed using unstructured data techniques applied in other research areas, to examine sentiments and affect dimensions, opinions, and emotions. This approach has proven to be useful in various areas, providing decision makers with data-driven approaches to business challenges (e.g., Ortigosa et al., 2014).
Finally, technological gaps have been a significant obstacle in the past two decades, which organizations have failed to overcome in both the for-profit and nonprofit sectors. However, the latter has found this problem especially challenging because of the tight funding environment in which they exist and the lack of grant programs focused 
on investment in technology. Companies and the public sector could become partners to mitigate these gaps because the latter must periodically renew their technological hardware to ensure they remain up-to-date, given the impact this has on performance (Chege et al., 2020).

In addition, universities can also be key players, helping nonprofits train their employees and volunteers to use computer hardware and skillfully provide services in virtual modes. Further research is needed to explore successful and best practices in establishing partnerships for nonprofits' reuse of this equipment, examining strategies and interorganizational networks in the nonprofit sector to identify opportunities (Bell et al., 2015) and prevent risks (Martínez, 2003; Santos \& Laureano, 2021). Exploring collaborative strategies in technology or other areas can also contribute to promoting these organizations' resilience.

In the long term, academic research could contribute to identifying the lessons learned from this pandemic crisis. The World Health Organization (WHO, 2021) has already warned that pandemic crises could become a part of future reality. Thus, the research directions identified by the present in-depth analysis of the literature could increase nonprofits' preparedness for similar future crises. These long-term topics are summarized in Table 5, which connects the topics to the clusters and also to the nonprofit areas and challenges.

Nonprofits have adopted different strategies to fight constraints arising from this pandemic crisis, for instance, eliminating services, delaying capital expenditures and routine maintenance, or freezing discretionary spending (Deitrick et al., 2020; Maher et al., 2020). Assessments are needed of these decisions' impacts up to the present. Researchers should further explore how appropriate decisions are from an organizational sustainability point of view. Other relevant questions are how they have impacted subsequent performance during the pandemic crisis and what strategies have been successful and in which fields of activity.

The strategies adopted or rejected by nonprofits have necessarily had a positive or negative impact on the populations they serve. Support provided to beneficiaries, awareness campaigns, and charity appeals, among other activities, were cancelled by various nonprofits due to their inability to provide adequate services (Wilke et al., 2020b). Future studies need to identify and measure these actions' consequences for nonprofits and their beneficiaries (e.g., $\mathrm{H}$. Zhang, 2020) to help these organizations pay attention to and assist the most seriously affected target populations.

Finally, researchers can help these organizations to contribute in more positive ways during future crises' predisaster mitigation and preparedness phase (Medel et al., 2020). Scholars should thus contribute to the design and implementation of preventive plans in order to minimize negative consequences. This research could provide significant advances in risk management theory.

\section{Discussion}

The present study's results include five main clusters of themes in the literature focused on nonprofit management during the COVID-19 pandemic, which also highlight the topics that still need to be addressed. The articles reviewed were written by academic researchers, who are heavily concentrated in Chinese and US contexts. The pandemic's earliest cases were reported in China, so the virus's effects were felt first in that country. The USA was also one of the most strongly affected nations because it had the most recorded COVID-19 deaths of any country worldwide (WHO, 2021). Thus, studies of US realities can be expected to deal with public health and socioeconomic crises.

Table 5 Nonprofits' challenges and long-term future research on nonprofit management

\begin{tabular}{|c|c|c|c|c|}
\hline Related cluster & $\begin{array}{l}\text { Nonprofit } \\
\text { area }\end{array}$ & $\begin{array}{l}\text { Nonprofits' } \\
\text { challenge }\end{array}$ & Future research topic & References \\
\hline $\begin{array}{l}\text { Cluster 3- } \\
\text { collaborative } \\
\text { models } \\
\text { Cluster 5-civil } \\
\text { society } \\
\text { participation }\end{array}$ & $\begin{array}{r}\text { Emergency } \\
\text { strategies }\end{array}$ & $\begin{array}{l}\text { Running activities } \\
\text { during a pandemic } \\
\text { crisis }\end{array}$ & $\begin{array}{l}\text { \#1: Investigating the strength and weaknesses of nonprofits' } \\
\text { strategies during the COVID-19 pandemic: How appropriate } \\
\text { were those strategies from an organizational sustainability } \\
\text { point of view? } \\
\text { \#2: Which strategies were successful and in which fields of } \\
\text { activity? }\end{array}$ & $\begin{array}{l}\text { Finchum-Mason et al. } \\
\text { (2020) }\end{array}$ \\
\hline $\begin{array}{l}\text { Cluster 2- } \\
\text { citizens } \\
\text { Cluster 4- } \\
\text { healthcare } \\
\text { access }\end{array}$ & Beneficiaries & $\begin{array}{l}\text { Supporting } \\
\text { beneficiaries as } \\
\text { much as possible }\end{array}$ & $\begin{array}{l}\text { \#3: Investigating the consequences for beneficiaries when } \\
\text { nonprofits stop providing assistance } \\
\text { \#4: Identifying the best practices and preventive plans to apply } \\
\text { in future pandemic crises that can minimize the negative } \\
\text { consequences for beneficiaries }\end{array}$ & $\begin{array}{l}\text { Medel et al. (2020); } \\
\text { Pitts (2020); H. } \\
\text { Zhang (2020) }\end{array}$ \\
\hline
\end{tabular}


This concentration of studies in the northern hemisphere, with fewer researchers addressing southern regions' realities, is also visible in the data on authorship affiliation. Overall, quite sparse research was found for the southern hemisphere, in which many developing countries are located, implying that COVID-19's impact on these nations' realities is being neglected due to academics' reduced contributions in those areas. Appeals have previously been made to increase the interoperability of research data repositories, and synergies among research communities would generate more equilibrium between the number of studies in the two hemispheres, thereby diminishing the gap between north and south (Hassan et al., 2019).

The current global situation includes the virus's spread and economies subjected to sudden stops, so academics have joined the efforts to accelerate the gathering of valid empirical knowledge on their societies' behalf. Research focused on the nonprofit sector has resulted in a significant number of articles published with multiple authorship by research teams. Various publishers have also clearly played a crucial role in making COVID-19-related research open access since the present results show that a large majority of articles are available free of charge. Journals have presented special issues of COVID-19-related contributions, which has also provided a public stage for discoveries in the nonprofit area.

Journal editors' communications advise authors to expect delays in the reviewing process and allow extra time for authors to submit revised versions of articles or reviewers to conclude the reviewing process. These special measures reflect how researchers have been directly affected by the pandemic, sometimes having to stop their scholarly activities for health reasons. Academics have also had to invest significant time in reinventing materials to teach online classes (Bryson \& Andres, 2020). In addition, inquiry- and interview-based research may have been interrupted due to fewer available nonprofit professionals or potential participants' lacking the skills needed to use the relevant digital tools.

\section{Themes Highlighted}

The five clusters identified (i.e., technology, citizens, collaborative models, healthcare access, and civil society participation) reveal an initial focus during the COVID-19 pandemic's first year on examining not only nonprofits' challenges but also the populations they serve. A particular emphasis was put on the effects of interruptions in assistance usually provided by nonprofits dedicated to children, adolescents, and their families (Lučić et al., 2020; Nisanci et al., 2020). Researchers found evidence that nonprofits are struggling to provide appropriate support to vulnerable population groups, namely refugees or children with developmental difficulties and their families. These individuals currently need help more than ever in terms of psychosocial support, distance learning equipment, or assistance with cohabitation issues (Rossitto, 2020; Wilke et al., 2020a, b).

To respond to this demand, nonprofits should be encouraged to adopt value-creating strategies focused on achieving cooperative advantages instead of competitive advantages (Strand \& Freeman, 2015). The present study shows evidence of success stories in which organizations from different sectors (i.e., nonprofits, governments, and companies) worked together to overcome constraints (e.g., Maserat et al., 2020; Tierney \& Boodoosingh, 2020). These studies offer lessons to nonprofits regarding how side-byside cooperation with other organizations in partnerships can facilitate service provision (Berry, 2020).

The technological gaps associated with the pandemic are often felt by companies but even more strongly by nonprofits, who lack the resources to invest in hardware, software, high-speed Internet connections, cloud computing, or improvements in their professionals' technology skills. Some authors see technology as the key to survival in times when people cannot meet face-to-face (e.g., Castka et al., 2020), while other case studies found that digital portals strengthen the collaboration between nonprofit organizations and the remaining sectors (Maserat et al., 2020). However, nonprofits often struggle to meet financial commitments and find the resources to provide services (Maher et al., 2020), and the resulting technology gaps make providing online services difficult, forcing some nonprofits to close their facilities and disrupt assistance to beneficiaries.

When no strategies are implemented to overcome these constraints, nonprofits cannot benefit from cyber-based strategies that can strengthen key principles of membership and participation. These strategies help foster communication between and among members, volunteers, supporters, and service recipients and establish forums for multidirectional communication and interpersonal interaction (Brainard \& Siplon, 2004). The Internet can save time and money in various management areas, providing benefits to nonprofit managers especially in administration, procurement, human resource management, logistics, training, volunteer recruitment, and fundraising (Lee et al., 2001). The COVID-19 pandemic also showed that nonprofits can provide online support (e.g., telemedicine) to reach populations that sometimes do not receive assistance due to distance. This digital transformation's lessons can be applied in the future to ensure that nobody is left behind.

In the literature reviewed, academics investigated civil society's role, finding evidence of the positive impact of citizen networks' mobilization to help public administrators meet challenges (Ding \& Riccucci, 2020). In contrast, other researchers explored how traditional societies' values 
still negatively affect families, especially given the restrictive policies implemented during the pandemic, thereby requiring nonprofits to respond adequately (Finchum-Mason et al., 2020). The articles reviewed for the present study also examine these organizations' part in supporting governments' efforts to ensure services are in accordance with public health guidelines, which the general population sometimes tends to ignore (Campos-Mercade et al., 2020).

\section{Implications for Practice, Policy, and Theory}

Researchers have accumulated additional knowledge over the first year of the COVID-19 pandemic that should help nonprofit practitioners and communities to pay closer attention to the most critical emerging issues and facilitate improvements in crisis management strategies. Using these scholars' contributions to theories of technological adoption, the nonprofit, public, and business sectors can follow best practices in this area to deal with challenges arising from the pandemic. Models based on the theory of acceptance and use of technology (Venkatesh, 2015) can expedite this process as nonprofits must revise their cultural values and communication practices to ensure that they encourage the use of information and communications technologies (Ihm \& Kim, 2021).

The literature also shows that nonprofits are struggling to attract and maintain material and human resources, so these organizations can exploit all the digital era's advantages to improve fundraising. That is, nonprofits can disclose additional information in their online spaces regarding their activities to build more trust in their relationships with stakeholders and thus increase online and offline donations (Zhou \& Ye, 2021). Contingency theory suggests that the way nonprofits respond to these technological challenges depends on these organizations' internal structure and strategies and the external environments in which nonprofits act (Bradshaw, 2009). Given the northern versus southern hemisphere divergences highlighted by the present study, nonprofit organizations may face different adaptation challenges according to their home and/or host country's political and socioeconomic realities.

When nonprofits seek to strengthen their ability to deal with crises, the literature reviewed underlines the advantages generated by leaders with effective interorganizational collaborative skills. Engaging in isolationist and competitive behaviors and strategies in the current pandemic context produces inadequate results. Cooperative strategies can also strengthen policymakers' role in vaccination programs since governments can actively engage with nonprofits whose proximity with vulnerable populations can promote the programs' success. Nonprofits can contribute by clarifying details and boosting their beneficiaries' confidence in the vaccine as these organizations' influence proved to be quite substantial in the adoption of nonpharmaceutical procedures (e.g., use of facemasks) (Galiatsatos et al., 2020).

Cooperative strategies can also be implemented to deal with increased domestic violence, providing support to nonprofits that were forced to abandon awareness campaigns seeking to increase reports of abuse or to eliminate harmful behaviors - a reality highlighted by the present literature review. In addition, assistance to and inclusion of migrants and/or refugees have been neglected during the pandemic. The population groups shown to be left behind can benefit from collaborations between nonprofit organizations and local governments. Researchers have found evidence that nonprofits play a prominent role in efforts to support immigrants by overcoming linguistic barriers that can prevent the effective dissemination of public policies (Wilson, 2013).

Finally, nonprofits need assistance to return programs to their full capacity that were partially abandoned during the COVID-19 pandemic due to volunteers' absence or decreased donations. Public funding lines should be made specifically available to the nonprofit sector. Smaller nonprofits are especially vulnerable because their Web-based accountability practices are not yet well developed due to their stakeholders' number and power, as suggested by stakeholder theory (Dainelli et al., 2013).

From a theoretical perspective, the present results show that studies of nonprofit management during the COVID19 pandemic are still scarce, constituting only a part of the entire research on this crisis. Despite academic journals' efforts to make articles accessible free of charge, editors and publishers need to implement more strategies to increase the submission of papers and reviewers' availability in order to ensure more articles are published, especially by journals dedicated to nonprofit topics, and in different geographies, other than the USA and China. The five clusters identified in the relevant literature comprise active lines of research, offering academics an overview of the areas in which scholars are seeking to provide evidence based on empirical research.

\section{Conclusion}

The COVID-19 pandemic has inspired unprecedented levels of research worldwide. The present findings unveil the themes addressed in academic articles on nonprofit management topics in response to this crisis, underlining the importance of research for this sector. The review generated a comprehensive map of academics' contributions thus far regarding nonprofit management during the pandemic. High-quality peer-reviewed articles were selected to identify 
clusters in this field's literature. Using text mining and visualization tools, the findings reveal that researchers focused on five themes during the first year: technology, citizens, collaborative models, healthcare access, and civil society participation. The results thus provide a theoretical synthesis of research trends, which were subjected to integrated analysis focused on how they are linked to the ongoing global crisis's realities. This knowledge can help nonprofits develop strategies to engage in this crisis and be better preparedness to future pandemics.

In addition, various inactive areas emerged from the data-research gaps that point to future directions for research based on the challenges practitioners currently faced due to the ongoing pandemic. Critical analysis also highlighted short- and long-term research topics that require more attention. The findings indicate different directions that could advance knowledge about management theory and practices to provide nonprofits with tools to face the enormous challenges presented by pandemics, thereby contributing to societies' ongoing well-being. Investigations into the identified areas will require varied competencies, thus emphasizing the need for research by multidisciplinary teams.

\section{Limitations}

As with any research, this study was subject to limitations. The data selection process restricted the articles reviewed to peer-reviewed publications included in the Web of Science and Scopus databases. The decision to limit the sample was taken because of the large number of studies covered by these databases and peer reviews' positive effect on studies' quality. However, these choices could be considered limitations by scholars who favor alternative databases or the inclusion of non-peer-reviewed publications.

The automated analysis method applied in this study also produced results in a shorter time so that the findings could still address the urgent need to respond appropriately to this pandemic crisis. Other researchers, nonetheless, prefer traditional systematic literature review techniques based on a manual analysis of each article. These limitations and the future avenues of research identified may inspire scholars to keep investigating the COVID-19 pandemic's challenges and impacts on nonprofits in order to improve their management and promote the achievement of their social goals.

Funding This publication/researh was partially supported by Fundação para a Ciência e Tecnologia throught project grant FCT UIDB/ 04466/2020, UIDP/04466/2020 and UID/GES/00315/2020, and also by Instituto Politécnico de Setúbal [RAADRI program].

\section{Declarations}

Conflict of interest The authors declare that they have no conflict of interest.

\section{References}

Akpan, I. J., Soopramanien, D., \& Kwak, D. H. (2020). Cutting-edge technologies for small business and innovation in the era of COVID-19 global health pandemic. Journal of Small Business and Entrepreneurship. https://doi.org/10.1080/08276331.2020. 1799294

Arik, M., Clark, L. A., \& Raffo, D. M. (2016). Strategic responses of non-profit organizations to the economic crisis. Academy of Strategic Management Journal, 15(1), 48-70.

Aristovnik, A., Ravšelj, D., \& Umek, L. (2020). A bibliometric analysis of covid-19 across science and social science research landscape. Sustainability (switzerland), 12(21), 1-30. https://doi. org/10.3390/su12219132

Baxter-Tomkins, T., \& Wallace, M. (2009). Recruitment and retention of volunteers in emergency services. Australian Journal on Volunteering, 14(5), 1-11. https://doi.org/10.1177/ $0095327 x 8200900107$

Bell, K., Tanner, J., Rutty, J., Astley-Pepper, M., \& Hall, R. (2015). Successful partnerships with third sector organisations to enhance the healthcare student experience: A partnership evaluation. Nurse Education Today, 35(3), 530-534. https:// doi.org/10.1016/j.nedt.2014.12.013

Bennett, N. J., Finkbeiner, E. M., Ban, N. C., Belhabib, D., Jupiter, S. D., Kittinger, J. N., Mangubhai, S., Scholtens, J., Gill, D., \& Christie, P. (2020). The COVID-19 pandemic, small-scale fisheries and coastal fishing communities. Coastal Management, 48(4), 336-347. https://doi.org/10.1080/08920753.2020.1766937

Berry, B. (2020). Teaching, learning, and caring in the post-COVID era. Phi Delta Kappan, 102(1), 14-17. https://doi.org/10.1177/ 0031721720956840

Bin-Nashwan, S. A., Al-Daihani, M., Abdul-Jabbar, H., \& Al-Ttaffi, L. H. A. (2020). Social solidarity amid the COVID-19 outbreak: Fundraising campaigns and donors' attitudes. International Journal of Sociology and Social Policy. https://doi.org/10. 1108/IJSSP-05-2020-0173

Bradshaw, P. (2009). A Contingency Approach to Nonprofit Governance. Nonprofit Management and Leadership, 20(4), 83-96. https://doi.org/10.1002/nml

Brainard, L. A., \& Siplon, P. D. (2004). Toward nonprofit organization reform in the voluntary spirit: Lessons from the Internet. Nonprofit and Voluntary Sector Quarterly, 33(3), 435-457. https://doi.org/10.1177/0899764004266021

Brañas-Garza, P., Jorrat, D., Alfonso-Costillo, A., Espín, A. M., Garcia, T., \& Kovárík, J. (2020). Exposure to the Covid-19 pandemic and generosity (Issue 103389). https://mpra.ub.unimuenchen.de/103389/

Bryson, J. R., \& Andres, L. (2020). Covid-19 and rapid adoption and improvisation of online teaching: Curating resources for extensive versus intensive online learning experiences. Journal of Geography in Higher Education, 44(4), 608-623. https://doi.org/ 10.1080/03098265.2020.1807478

Calheiros, A. C., Moro, S., \& Rita, P. (2017). Sentiment classification of consumer-generated online reviews using topic modeling. Journal of Hospitality Marketing \& Management, 26(7), 675-693. https://doi.org/10.1080/19368623.2017.1310075

Campos-Mercade, P., Meier, A. N., Schneider, F. H., \& Wengström, E. (2020). Prosociality predicts health behaviors during the 
COVID-19 pandemic (No. 346). https://doi.org/10.5167/uzh187672

Castka, P., Searcy, C., \& Fischer, S. (2020). Technology-enhanced auditing in voluntary sustainability standards: The impact of COVID-19. Sustainability (switzerland), 12(11), 1-24. https:// doi.org/10.3390/su12114740

Chege, S. M., Wang, D., \& Suntu, S. L. (2020). Impact of information technology innovation on firm performance in Kenya. Information Technology for Development, 26(2), 316-345. https://doi. org/10.1080/02681102.2019.1573717

Corburn, J., Vlahov, D., Mberu, B., Riley, L., Caiaffa, W. T., Rashid, S. F., Ko, A., Patel, S., Jukur, S., Martínez-Herrera, E., Jayasinghe, S., Agarwal, S., Nguendo-Yongsi, B., Weru, J., Ouma, S., Edmundo, K., Oni, T., \& Ayad, H. (2020). Slum health: Arresting COVID-19 and improving well-being in urban informal settlements. Journal of Urban Health, 97(3), 348-357. https://doi.org/10.1007/s11524-020-00438-6

Curtis, L., Edwards, C., Fraser, K. L., Gudelsky, S., Holmquist, J., Thornton, K., \& Sweetser, K. D. (2010). Adoption of social media for public relations by nonprofit organizations. Public Relations Review, 36(1), 90-92. https://doi.org/10.1016/j.pubrev. 2009.10.003

Dainelli, F., Manetti, G., \& Sibilio, B. (2013). Web-based accountability practices in non-profit organizations: The case of national museums. VOLUNTAS: International Journal of Voluntary and Nonprofit Organizations, 24(3), 649-665. https://doi.org/10. 1007/s11266-012-9278-9

de Broeck, W. (2018). Crowdfunding platforms for renewable energy investments: An overview of best practices in the EU. International Journal of Sustainable Energy Planning and Management, 15, 3-10. https://doi.org/10.5278/ijsepm.2018.15.2

Deitrick, L., Tinkler, T., Young, E., Strawser, C. C., \& Meschen, C. (2020). Nonprofit Sector response to COVID-19: The immediate impacts of the COVID-19 pandemic on San Diego County nonprofits. University of San Diego.

Ding, F., \& Riccucci, N. M. (2020). The value of alumni networks in responding to the public administration theory and practice: Evidence from the COVID-19 pandemic in China. Administrative Theory and Praxis, 42(4), 588-603. https://doi.org/10.1080/ 10841806.2020.1798694

Eurostat. (2021). Third quarter of 2020 Government debt up to 97.3 $\%$ of GDP in euro area. News realease 13/2021. (Issue January). https://ec.europa.eu/eurostat/documents/portlet_file_entry/ 2995521/2-21012021-AP-EN.pdf/a3748b22-e96e-7f62-ba05$11 \mathrm{c} 7192 \mathrm{e} 32 \mathrm{f} 3$

Fernandes, E., Moro, S., Cortez, P., Batista, F., \& Ribeiro, R. (2021). A data-driven approach to measure restaurant performance by combining online reviews with historical sales data. International Journal of Hospitality Management. https://doi.org/10. 1016/j.ijhm.2020.102830

Finchum-Mason, E., Husted, K., \& Suárez, D. (2020). Philanthropic foundation responses to COVID-19. Nonprofit and Voluntary Sector Quarterly, 49(6), 1129-1141. https://doi.org/10.1177/ 0899764020966047

Galiatsatos, P., Monson, K., Oluyinka, M. J., Negro, D. R., Hughes, N., Maydan, D., Golden, S. H., Teague, P., \& Hale, W. D. (2020). Community calls: Lessons and insights gained from a medical-religious community engagement during the COVID-19 pandemic. Journal of Religion and Health, 59(5), 2256-2262. https://doi.org/10.1007/s10943-020-01057-w

Guerreiro, J., Rita, P., \& Trigueiros, D. (2016). A text mining-based review of cause-related marketing literature. Journal of Business Ethics, 139(1), 111-128. https://doi.org/10.1007/s10551-0152622-4

Hassan, S. U., Visvizi, A., \& Waheed, H. (2019). The 'who' and the 'what' in international migration research: Data-driven analysis of Scopus-indexed scientific literature. Behaviour and Information Technology, 38(9), 924-939. https://doi.org/10.1080/ 0144929X.2019.1583282

Ihm, J., \& Kim, E. (2021). When nonprofit organizations meet information and communication technologies: How organizational culture influences the use of traditional, digital, and sharing media. VOLUNTAS: International Journal of Voluntary and Nonprofit Organizations, 32(3), 678-694. https://doi.org/10. 1007/s11266-021-00335-9

Lee, T. E., Chen, J. Q., \& Zhang, R. (2001). Utilizing the internet as a competitive tool for non-profit organizations. Journal of Computer Information Systems, 41(3), 26-31. https://doi.org/10. 1080/08874417.2001.11647004

Lučić, L., Brkljačić, T., \& Brajša-Žganec, A. (2020). Effects of COVID-19 related restrictive measures on parents of children with developmental difficulties. Journal of Children's Services, 15(4), 229-234. https://doi.org/10.1108/JCS-07-2020-0041

Maher, C. S., Hoang, T., \& Hindery, A. (2020). Fiscal responses to COVID-19: Evidence from local governments and nonprofits. Public Administration Review. https://doi.org/10.1111/puar. 13238

Martínez, C. V. (2003). Social alliances for fundraising: How spanish nonprofits are hedging the risks. Journal of Business Ethics, 47(3), 209-222. https://doi.org/10.1023/A:1026212902564

Maserat, E., Jafari, F., Mohammadzadeh, Z., Alizadeh, M., \& Torkamannia, A. (2020). COVID-19 \& an NGO and university developed interactive portal: A perspective from Iran. Health and Technology, 10(6), 1421-1426. https://doi.org/10.1007/ s12553-020-00470-1

Mas-Tur, A., Modak, N. M., Merigó, J. M., Roig-Tierno, N., Geraci, M., \& Capecchi, V. (2019). Half a century of quality \& quantity: A bibliometric review. Quality and Quantity, 53(2), 981-1020. https://doi.org/10.1007/s11135-018-0799-1

Medel, K., Kousar, R., \& Masood, T. (2020). A collaborationresilience framework for disaster management supply networks: A case study of the Philippines. Journal of Humanitarian Logistics and Supply Chain Management, 10(4), 509-553. https://doi.org/10.1108/JHLSCM-09-2019-0066

Modak, N. M., Lobos, V., Merigó, J. M., Gabrys, B., \& Lee, J. H. (2020). Forty years of computers \& chemical engineering: A bibliometric analysis. Computers and Chemical Engineering, 141, 614-629. https://doi.org/10.1016/j.compchemeng.2020. 106978

Nisanci, A., Kahraman, R., Alcelik, Y., \& Kiris, U. (2020). Working with refugees during COVID-19: Social worker voices from Turkey. International Social Work, 63(5), 685-690. https://doi. org/10.1177/0020872820940032

Ortigosa, A., Martín, J. M., \& Carro, R. M. (2014). Sentiment analysis in facebook and its application to e-learning. Computers in Human Behavior, 31(1), 527-541. https://doi.org/10.1016/j.chb. 2013.05.024

Park, E., Kang, J., Choi, D., \& Han, J. (2020). Understanding customers' hotel revisiting behaviour: A sentiment analysis of online feedback reviews. Current Issues in Tourism, 23(5), 605-611. https://doi.org/10.1080/13683500.2018.1549025

Pitts, J. (2020). Covid-19, county lines and the seriously "left behind." Journal of Children's Services, 15(4), 209-213. https:// doi.org/10.1108/JCS-06-2020-0024

Rossitto, S. (2020). Isolated together: Amplified vulnerabilities in Japan's children's homes. Asia-Pasific Journal: Japan Focus, 18(18), 1-9.

Ruelle, O., \& Peverelli, P. (2016). The discursive construction of identity through interaction on social media in a Chinese NGO. Chinese Journal of Communication, 4750(February), 1-26. https://doi.org/10.1080/17544750.2016.1217899 
Salamon, L. M., \& Sokolowski, S. W. (2016). Beyond nonprofits: Reconceptualizing the third sector. VOLUNTAS: International Journal of Voluntary and Nonprofit Organizations, 27(4), 1515-1545. https://doi.org/10.1007/s11266-016-9726-Z

Salamon, L. M., Sokolowski, S. W., \& Haddock, M. A. (2011). Measuring the economic value of volunteer work globally: Concepts, estimates, and a roadmap to the future. Annals of Public and Cooperative Economics, 82(3), 217-252. https://doi. org/10.1111/j.1467-8292.2011.00437.x

Santos, M. R. C., \& Laureano, R. (2021). Developing a vulnerabilitybased conceptual model for managing risk in non-profit projects: A multicase study in a European country. Public Management Review, 1-27. https://doi.org/10.1080/14719037.2021.1972685.

Santos, M. R. C., Laureano, R., \& Moro, S. (2020). Unveiling research trends for organizational reputation in the nonprofit sector. VOLUNTAS: International Journal of Voluntary and Nonprofit Organizations, 31, 56-70. https://doi.org/10.1007/ s11266-018-00055-7

Saxton, G. D., \& Wang, L. (2014). The social network effect: The determinants of giving through social media. Nonprofit and Voluntary Sector Quarterly, 43(5), 850-868. https://doi.org/10. $1177 / 0899764013485159$

Saxton, G. D., \& Waters, R. D. (2014). What do stakeholders like on facebook? Examining public reactions to nonprofit organizations' informational, promotional, and community-building messages. Journal of Public Relations Research, 26(3), 280-299. https://doi.org/10.1080/1062726X.2014.908721

Selamet, J. (2020). Human-centered design approach toward the physical activity initiative for work-from-home workers during the COVID-19 outbreak. International Journal of Designed Objects, 14(2), 1-17. https://doi.org/10.18848/2325-1379/CGP/ V14I02/1-17

Shah, S. H. H., Lei, S., Ali, M., Doronin, D., \& Hussain, S. T. (2019). Prosumption: Bibliometric analysis using HistCite and VOSviewer. Kybernetes, 49(3), 1020-1045. https://doi.org/10.1108/ K-12-2018-0696

Shaw, S., \& Allen, J. B. (2009). “ To be a business and to keep our humanity" a critical management studies analysis of the relationship between a funder and nonprofit community organizations. Nonprofit Management and Leadership, 20(4), 83-96. https://doi.org/10.1002/nml

Simo, G., \& Bies, A. L. (2007). The role of nonprofits in disaster response: An expanded model of cross-sector collaboration. Public Administration Review, 67(SUPPL. 1), 125-142. https:// doi.org/10.1111/j.1540-6210.2007.00821.x

Singh, S., Prakash, C., \& Ramakrishna, S. (2020). Three-dimensional printing in the fight against novel virus COVID-19: Technology helping society during an infectious disease pandemic. Technology in Society. https://doi.org/10.1016/j.techsoc.2020.101305

Smith, D. H., Stebbins, R. A., \& Dover, M. A. (2006). Nonprofit terms \& concepts. Indiana University Press.

Strand, R., \& Freeman, R. E. (2015). Scandinavian cooperative advantage: The theory and practice of stakeholder engagement in scandinavia. Journal of Business Ethics, 127(1), 65-85. https:// doi.org/10.1007/s10551-013-1792-1

Tafesse, W., \& Wood, B. P. (2021). Followers' engagement with instagram influencers: The role of influencers' content and engagement strategy. Journal of Retailing and Consumer Services. https://doi.org/10.1016/j.jretconser.2020.102303

Tierney, A., \& Boodoosingh, R. (2020). Challenges to NGOs' ability to bid for funding due to the repatriation of volunteers: The case of Samoa. World Development. https://doi.org/10.1016/j.world dev.2020.105113

Tran, T., Hoang, A. D., Nguyen, Y. C., Nguyen, L. C., Ta, N. T., Pham, Q. H., Pham, C. X., Le, Q. A., Dinh, V. H., \& Nguyen, T. T. (2020). Toward sustainable learning during school suspension: Socioeconomic, occupational aspirations, and learning behavior of vietnamese students during COVID-19. Sustainability (Switzerland). https://doi.org/10.3390/su12104195

Trautmann, K., Maher, J. K., \& Motley, D. G. (2007). Learning strategies as predictors of transformational leadership: The case of nonprofit managers. Leadership and Organization Development Journal, 28(3), 269-287. https://doi.org/10.1108/ 01437730710739675

Tzifakis, N., Petropoulos, S., \& Huliaras, A. (2017). The impact of economic crises on NGOs: The case of greece. VOLUNTAS: International Journal of Voluntary and Nonprofit Organizations, 28(5), 2176-2199. https://doi.org/10.1007/s11266-017-9851-3

van Eck, N. J., \& Waltman, L. (2009). How to normalize cooccurrence data? An analysis of somewell-known similarity measures. Journal of the American Society for Information Science and Technology, 60(8), 1635-1651. https://doi.org/10.1002/asi

van Eck, N. J., \& Waltman, L. (2010). Software survey: VOSviewer, a computer program for bibliometric mapping. Scientometrics, 84(2), 523-538. https://doi.org/10.1007/s11192-009-0146-3

Venkatesh, V. (2015). Technology acceptance model and the unified theory of acceptance and use of technology. Wiley Encyclopedia of Management. https://doi.org/10.1002/9781118785317. weom070047

Verma, S., \& Gustafsson, A. (2020). Investigating the emerging COVID-19 research trends in the field of business and management: A bibliometric analysis approach. Journal of Business Research, 118(July), 253-261. https://doi.org/10.1016/j.jbusres. 2020.06 .057

Wang, S., Shrestha, N., Subburaman, A. K., Wang, J., Wei, M., \& Nagappan, N. (2021). Automatic Unit Test Generation for Machine Learning Libraries: How Far Are We? 2021 IEEE/ACM $43 r$ International Conference on Software Engineering (ICSE), 1548-1560. https://doi.org/10.1109/icse43902.2021.00138

WHO. (2021). Coronavirus disease (COVID-19) pandemic. Coronavirus Disease (COVID-19) Pandemic Dashboard. https:// covid19.who.int/region/amro/country/us

Wilke, N. G., Howard, A. H., \& Goldman, P. (2020a). Rapid return of children in residential care to family as a result of COVID-19: Scope, challenges, and recommendations. Child Abuse and Neglect. https://doi.org/10.1016/j.chiabu.2020.104712.

Wilke, N. G., Howard, A. H., \& Pop, D. (2020b). Data-informed recommendations for services providers working with vulnerable children and families during the COVID-19 pandemic. Child Abuse and Neglect. https://doi.org/10.1016/j.chiabu.2020. 104642.

Williams, D., Lawrence, J., Hong, Y. R., \& Winn, A. (2020). TeleICUs for COVID-19: A look at national prevalence and characteristics of hospitals providing teleintensive care. Journal of Rural Health, 37, 133-141. https://doi.org/10.1111/jrh.12524

Wilson, C. E. (2013). Collaboration of nonprofit organizations with local government for immigrant language acquisition. Nonprofit and Voluntary Sector Quarterly, 42(5), 963-984. https://doi.org/ 10.1177/0899764012461400

Yu, Y., Li, Y., Zhang, Z., Gu, Z., Zhong, H., Zha, Q., Yang, L., Zhu, C., \& Chen, E. (2020). A bibliometric analysis using VOSviewer of publications on COVID-19. Annals of Translational Medicine, 8(13), 1-11. https://doi.org/10.21037/atm-20-4235

Zhang, H. (2020). The influence of the ongoing COVID-19 pandemic on family violence in China. Journal of Family Violence. https:// doi.org/10.1007/s10896-020-00196-8

Zhang, L., Zhao, W., Sun, B., Huang, Y., \& Glänzel, W. (2020). How scientific research reacts to international public health emergencies: A global analysis of response patterns. Scientometrics, 124(1), 747-773. https://doi.org/10.1007/s11192-020-03531-4

Zhao, T., \& Wu, Z. (2020). Citizen-state collaboration in combating COVID-19 in China: Experiences and lessons from the 
perspective of co-production. American Review of Public Administration, 50(6-7), 777-783. https://doi.org/10.1177/ 0275074020942455

Zhou, H., \& Ye, S. (2021). Fundraising in the digital era: Legitimacy, social network, and political ties matter in China. VOLUNTAS: International Journal of Voluntary and Nonprofit Organizations, 32(2), 498-511. https://doi.org/10.1007/s11266-019-00112-9
Publisher's Note Springer Nature remains neutral with regard to jurisdictional claims in published maps and institutional affiliations. 